\title{
Hematological and histopathological changes in medular aplasia resulting from Ehrlichia canis infection in a Border collie dog
}

\author{
Alterações hematológicas e histopatológicas na aplasia medular \\ decorrente da infecção por Ehrlichia canis em cão da raça Border Collie
}

\section{Carolina Araújo Neves ${ }^{1^{*}}\left(\mathbb{D}\right.$, Reiner Silveira de Moraes $^{1}$ (D), Kaline Ogliari² (D), Antônio Carlos Severino Neto ${ }^{3}$ (1), Dirceu Guilherme de Souza Ramos ${ }^{4} \mathbb{B}$, Klaus Casaro Saturnino ${ }^{4}[\mathbb{B}$}

\begin{abstract}
The Canine Monocytic Ehrlichiosis (CME) is an infectious disease that commonly affects dogs of all breeds and ages. It is caused by the bacterium Ehrlichia canis and is transmitted by the tick Rhipicephalus sanguineus. The disease may present itself in the acute, subclinical, and chronic forms. The present study reports the case of a 2-year-old male Border Collie with advanced stage CME, attended at the Pet Clinic of the Veterinary Hospital of the University Federal de Jataí, which resulted in medullary aplasia. The diagnosis of marrow aplasia was based on the necroscopic and histopathological examinations. At necropsy, the diaphyses of the long bones were filled with diffuse, strongly whitish and pasty tissue, typical of the adipose tissue, also found in the femoral epiphyses. The histopathology showed unilocular adipose tissue as the major constituent of the bone marrow and rare islands of marrow cells. These findings were compatible with severe hypoplasia of the red bone marrow and hyperplasia of the white bone marrow, affecting hematopoiesis, resulting in the laboratory alterations observed in the hematocrit, WBC, and plateletogram.
\end{abstract}

KEYWORDS: Anemia; Antibodies; Hypoplasia; Leukopenia; Necropsy.

RESUMO: A erliquiose monocítica canina (EMC) é uma doença infecciosa que comumente afeta cáes de todas as raças e idades. Causada pela bactéria Ehrlichia canis e transmitida pelo carrapato Rhipicephalus sanguineus, a doença pode apresentar-se nas formas aguda, subclínica e crônica. O presente trabalho relata o caso de um cão, raça Border Collie, macho, 2 anos de idade, com EMC em estágio avançado, atendido no Setor de Clínica de Animais de Companhia do Hospital Veterinário da Universidade Federal de Jataí, caso este que resultou em aplasia medular. O diagnóstico da aplasia de medula baseou-se na realizaçáo de exames necroscópico e histopatológico. Na necropsia verificou-se a diáfise de ossos longos preenchida por tecido difuso, severamente esbranquiçado e pastoso, característico de tecido adiposo, também encontrado em epífises femorais. No histopatológico foi verificado tecido adiposo unilocular como maior constituinte da medula óssea e raras ilhas de células medulares. Esses achados foram compatíveis com hipoplasia severa de medula óssea vermelha e hiperplasia de medula óssea branca, afetando a hematopoiese resultando nas alterações laboratoriais verificadas no eritrograma, leucograma e plaquetograma.

PALAVRAS-CHAVE: Anemia; Anticorpos; Hipoplasia; Leucopenia; Necropsia.

\section{INTRODUCTION}

The Canine Monocytic Erliquiosis (CME) is an infectious disease transmitted by the tick Rhipicephalus sanguineus sensu lato with the bacterium Erhlichia canis as its etiological agent (MYLONAKIS; THEODOROU, 2017). E. canis can be distributed throughout the organism of the dog, thus being able to access organs such as the liver, spleen, bone marrow, and lymph nodes, where they exhibit a significant multiplication capacity. In addition, the bacterium has an affinity for monocytic cells and can infect all types of dogs, regardless of age and sex (PROCAJLO et al., 2011).

According to ALMOSNY et al. (2002), in dogs, the infection of monocytes by $E$. canis develops in three phases. First, the elementary corpuscle enters the monocytic cell by 
phagocytosis and then multiplies through binary fission within the phagosome. After a period ranging from 3 to 5 days, the elementary corpuscles cluster within the cytoplasm and form the initial corpuscles. The maturation and clustering of the initial corpuscles is observed from 7 to 12 days later, giving rise to the morula which, when ruptured, causes the release of elementary corpuscles that restart the infection cycle in other monocytes.

The clinical manifestations observed are due to anemia and immunological compromise, represented by laboratory changes that showed neutropenia and thrombocytopenia (LAPPIN, 2015). In its chronic phase, CME may develop with clinical changes, which include liver and splenic tumors, immune-mediated hemolytic anemia, epistaxis, hematomas, endocarditis, polyarthritis, and medullary hypoplasia, which can result in severe anemia, thrombocytopenia, and leukopenia (COCKWILL et al., 2009).

Laboratory alterations should be interpreted based on the evaluation of the stage of the infection and the limitations of the available tests. Infected animals that are in the chronic phase of the disease, for example, may be positive on serology and negative on PCR due to reduction of cells by bone marrow damage (NAKAGHI et al., 2008). MYLONAKIS; THEODOROU (2017). UENO et al. (2009) pointed out that after the incubation period of the disease ( 8 to 20 days), the infection may develop with acute, subclinical, and chronic phases, and the chronic phase may lead to the occurrence of bone marrow aplasia, pancytopenia, and high mortality due to sepsis or severe hemorrhage.

The presentation of cases like that reported in this study becomes essentially relevant considering the possibility of bone marrow aplasia with a possible infectious origin in dogs infected by E. canis, (REILLY; DOLAN, 1991). In this context, the objective of the present study was to present a case of medullary aplasia due to infection by Erblichia canis, focusing on the hematological and histopathological changes of the disease.

\section{CASE REPORT}

A male Border Collie dog, approximately two years old, was attended at the Pet Clinic of the Veterinary Hospital of the Federal University of Jataí presenting paresis and prostration. Physical examination confirmed apathy, besides pale ocular and oral mucous membranes (Figure 1), dehydration (8-10\%), hyperthermia $\left(39.6^{\circ} \mathrm{C}\right)$, tachycardia $(140 \mathrm{bpm})$, tachypnea $(70 \mathrm{mrm})$, presence of hematoma and edema in the left pelvic limb. The anamnesis revealed treatment, without prescription, based on doxycycline 25 days ago at a dose of $3.14 \mathrm{mg} / \mathrm{kg}$ SID, below the recommended dose $(5-10 \mathrm{mg} / \mathrm{kg}$, BID) (FOURIE et al., 2015; SAVADELIS et al., 2018).

Complementary tests were performed, including an antibody detection test (Snap 4Dx Plus - IDEXX), with a positive result for Ehrlichia canis. The complete blood count (CBC) showed a hematocrit of $11 \%$ (ref. 37-55\%) and a platelet count

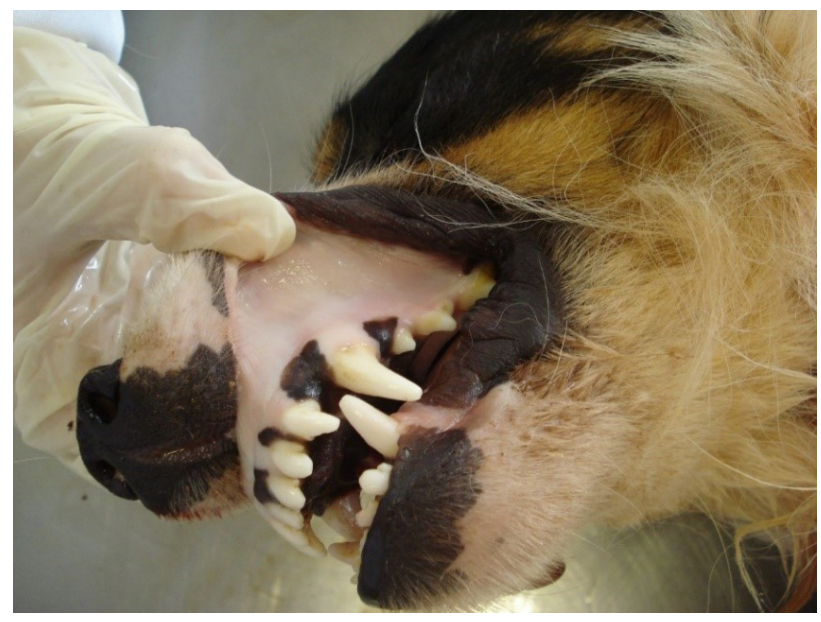

Figure 1. Dog with pale oral mucosa.

of $20,000 / \mu \mathrm{l}$, below the minimum reference value $(150,000 / \mu \mathrm{l})$ (GANT et al., 2020). In addition, the white blood cells (WBC) revealed a marked leukopenia $(3,420 / \mu \mathrm{l}$, ref. $8,000-16,000 / \mu \mathrm{l})$

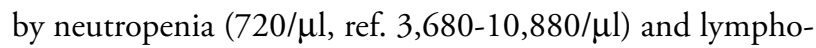
penia $(692 / \mu \mathrm{l}$, ref. $2,400-7,680 / \mu \mathrm{l})$. Evaluation of liver and kidney biochemistry was not performed due to the rapid progression of the patient to death, although the sample was collected. Intensive treatment was indicated, with the following therapeutic protocol: Doxycycline, $6 \mathrm{mg} / \mathrm{kg}$, BID, orally (VO); Maropitant citrate $\left(\right.$ Cerenia $\left.^{\circledR}\right), 1 \mathrm{~m} / \mathrm{kg}$, BID, subcutaneous (SC); Dexamethasone, $0.3 \mathrm{mg} / \mathrm{kg}$, SID, intravenous (IV); Dipyrone, $25 \mathrm{mg} / \mathrm{kg}$, TID, IV and vitamin supplement $\left(\right.$ Bionew $\left.^{\circledR}\right) 0.2 \mathrm{ml} / \mathrm{kg}$, SID, IV.

The animal, even under intensive treatment and supervision, suffered cardiorespiratory arrest, and even after the adoption of a Cardiopulmonary Resuscitation Protocol (CRP) (FLETCHER et al., 2012) with seven cycles, it died. In the CRP protocol, atropine sulfate $\left(\right.$ Hytropin $\left.{ }^{\circledR}\right) 0.03 \mathrm{mg} / \mathrm{kg}$ (due to marked bradycardia) and adrenaline were used. Initially, adrenaline was administered at a dose of $0.01 \mathrm{mg} / \mathrm{kg}$ in three serial applications; however, due to the animal's irresponsiveness, a new application at a dose of $0.1 \mathrm{mg} / \mathrm{kg}$ was performed, but without success.

The animal was sent to the Veterinary Pathology and Parasitology Laboratory in the Federal University of Jataí (UFJ) to be submitted to necroscopic examination for diagnostic purposes. The necropsy showed that, despite the appropriate body condition for the breed, the mucous membranes were diffusely whitish, presenting an extensive focal suffusion in the lateroposterior femoral region of the skin of the left hind limb. On cutting, a delimited caseous abscess and an adjacent serosanguinous exudation (phlegmon) were observed, suggestive of contaminated intramuscular administration of medication. A discrete accumulation of serosanguinous fluid was observed inside the thoracic cavity. The visceral serosa were 
pale, and the urinary bladder presented multifocal ecchymoses in its mucosa. In addition, the medullary cavities of long bones such as femur and humerus were filled with diffuse and strongly whitish tissue with a pasty consistency, typical of adipose tissue (Figure 2). The same tissue type was found in the femoral epiphyses, bilaterally (Figure 3).

The histopathological findings showed the presence of slightly hypoplastic lymphoid follicles in the spleen, with rare erythrocytic cells in the red pulp, besides a bone marrow formed mainly by unilocular adipose tissue, with small and rare islands of medullary cells (Figure 4), compatible with severe hypoplasia of the red bone marrow and hyperplasia of the white one, non-functional for hematopoiesis. Thus, based on the clinical, laboratory, and pathological findings, we concluded that this was a case of medullary aplasia secondary to ehrlichiosis.

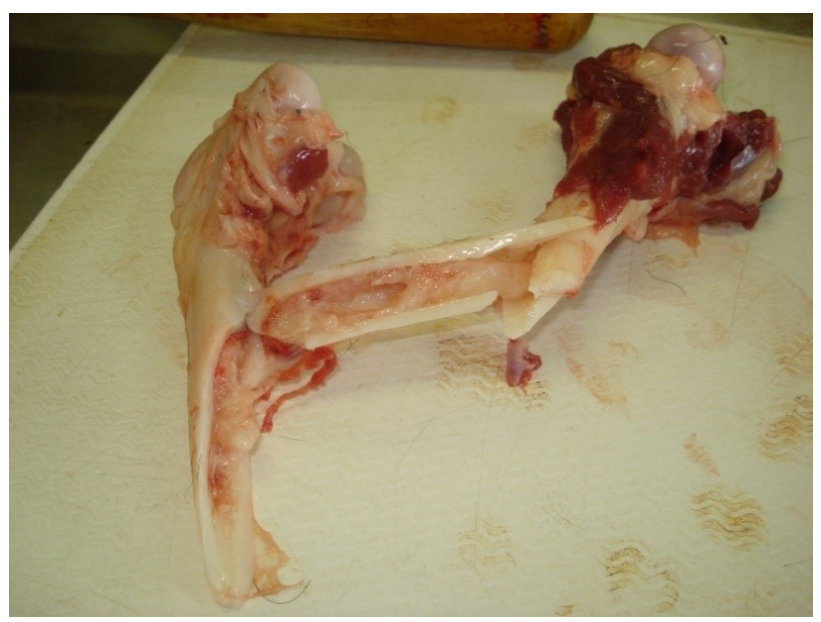

Figure 2. Femur medullary cavity filled with predominantly adipose tissue.

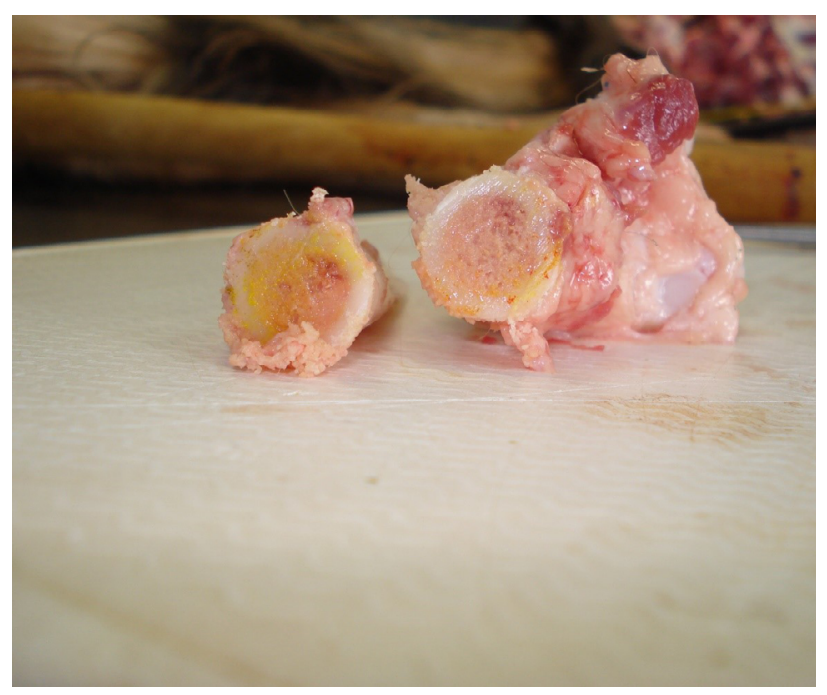

Figure 3. Cross section of femoral epiphyses filled mainly with adipose tissue (white bone marrow replacing the red bone marrow).

\section{DISCUSSION}

Canine Monocytic Ehrlichiosis (CME) has a high morbidity and mortality rate in dogs, therefore being an infectious disease of great importance in Veterinary Medicine (RODRÍGUEZALARCÓN et al., 2020). Among the forms of presentation of CME mentioned by Procajlo et al. (2011), the chronic form is the most consistent with the present report. Epidemiologically, no factor inherent to the animal in this report, such as race, age, or sex, justifies the occurrence of ehrlichiosis, since there is no trend (SOUZA et al., 2012).

The clinical manifestations of CME are varied and the intensity varies according to the clinical stage of the disease (MYLONAKIS; THEODOROU, 2017). In subclinical infections, clinical manifestations are mild, with only hematological changes. However, in some cases, hyporexia, limb edema, hemorrhages, and mucosal pallor can be observed (SOUZA et al., 2012). Thrombocytopenia is the most common hematological alteration, being found in about $80 \%$ of cases. Nevertheless, other changes are described, such as non-regenerative anemia, leukopenia, and neutropenia, especially related to chronic bone marrow hypoplasia, evidenced by the whitish aspect of the epiphyseal bone marrow (FIGHERA; GRAÇA, 2011). In addition, lymphopenia or lymphocytosis are mentioned as additional abnormalities (MYLONAKIS; THEODOROU, 2017). In the acute phase, clinical manifestations are considered nonspecific, being commonly observed pyrexia, hypophagia, apathy, epistaxis, hematuria, weight loss, claudication, besides respiratory symptoms that included dyspnea and mucopurulent nasal secretions (PROCAJLO et al., 2011).

According to SOUSA et al. (2010), the clinical manifestations of the subclinical and acute phases may present themselves in a mild or severe form in the chronic phase. Additionally, RODRÍGUEZ-ALARCÓN et al. (2020) reported that cases that evolved to the chronic phase may present pancytopenia

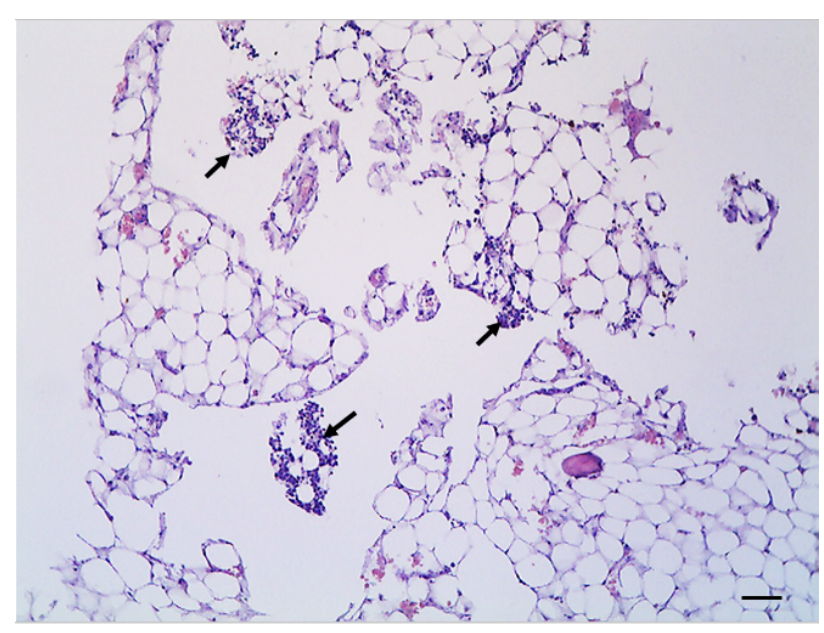

Figure 4. Dog, bone marrow. Microscopic image with the arrows indicating scanty and small clusters of erythropoietic and lymphopoietic cells (red bone marrow), surrounded by abundant adipose tissue (white bone marrow). 
associated with medullary aplasia, hemorrhagic diathesis, and general debilitation, which corroborates the findings of this report, that found leukopenia, hematuria, hematomas, pale oral and ocular mucosa, and prostration. Phlegmons and abscesses may also be found, as in the present case, due to leukopenia, associated with the breakdown of the protective skin barrier (CONCEIÇÃO; SANTOS, 2011).

In the present case, there is no report of intramuscular drug administration or puncture wounds, a fact that may have been omitted in the anamnesis, but the necroscopic findings are strongly suggestive. In addition, the patient presented severe thrombocytopenia and intense anemia, and these changes are suggestive of bone marrow involvement in a chronic phase (FELDMAN et al., 2000). In these cases, it is indicated the puncture or biopsy of the bone marrow in order to identify which changes are present and the evolution of the blood alterations (HARVEY, 2001). However, the procedure was not performed. Nevertheless, the histopathology of the bone marrow revealed severe and diffuse red marrow hypoplasia.

The marked anemia, pallor of mucous membranes, and the reduced hematocrit were clinical and laboratory parameters, which demonstrated the need for blood transfusion (TERRA, 2010). GOOGS (2020) recommended transfusing dogs with hematocrit lower than $12 \%$, even if there are no evident clinical manifestations. However, the animal died before the procedure was performed.

The diagnosis of CME can be made based on hematological and serological tests and polymerase chain reaction (PCR). Nevertheless, due to the lack of financial support of the tutor to perform the test, we chose the serological test associated with hematological and clinical changes of the animal, given the severity of the clinical picture (UENO et al., 2009). According to NAKAGHI et al. (2008), the serological test to detect antibodies to $E$. canis can be performed through the indirect immunofluorescence test for antibody detection (IFI) or Dot-Blot-ELISA, which detect IgG antibodies. In this case, the use of the SNAP 4DX Plus test with high sensitivity and specificity, by means of the ELISA technique, was used as a confirmatory diagnostic result for the patient in question in association with the anatomopathological findings and presented symptomatology (IDEXX, 2016). Not least important, laboratory and clinical changes contributed to the diagnostic conclusion of CME.

Given the diagnosis of CME, the first therapeutic option was the use of doxycycline, a semisynthetic tetracycline used as a first-line drug in the treatment of CME (MYLONAKIS; THEODOROU, 2017). The recommended dose according to previous literature is $5 \mathrm{mg} / \mathrm{kg}$, BID, VO for 28 days. However, there is a recommendation to use a dose ranging from 5 to $10 \mathrm{mg} / \mathrm{kg}$, SID or BID depending on the case (SOUZA et al., 2012; MOTA et al., 2019). As such, we opted for the use of an intermediate dose, in this case, $6 \mathrm{mg} / \mathrm{kg}, \mathrm{BID}$, VO for 28 days. SCHULZ et al. (2011) mentioned side effects caused by the use of doxycycline in dogs, such as nausea and vomiting, both verified in the animal of this report after the start of the drug therapy.

According to FOURIE et al. (2015), doxycycline concentrates in the liver, more precisely in the bile, and is excreted in the urine and feces in high concentrations in its active form. SCHULZ et al. (2011) pointed out that very little is known about the hepatotoxicity caused by doxycycline in dogs, since many studies have been conducted in rodents. Therefore, it is believed that the changes generally observed in the liver enzymes are attributed, for example, to the lipophilic characteristic of doxycycline that allows its penetration into the cell wall and accumulation in the hepatocytes. Considering the vomiting presented by the animal in this report, these authors claim that due to the high absorption in the small intestine as well as to disturbances in the intestinal microflora, vomiting and diarrhea may occur as side effects of the doxycycline use.

Considering the renal route as one of the routes of elimination of doxycycline, SANTIAGO et al. (2017) pointed out the drug as susceptible to nephrotoxicity since its percentage of elimination is of approximately $20 \%$ through the urinary tract. The action of the drug can reduce the glomerular filtration rate (GFR) causing ischemia in the efferent arteriole, which can lead to increased serum creatinine levels. Due to the rapid evolution to death of the animal and the need for emergency intervention due to the clinical and hematological findings at the time of the consultation, the dosage of urea and creatinine was not performed and, therefore, the real effect of the use of doxycycline in the animal of this study is unknown.

The sample collected for biochemical evaluation was not processed, since it should be sent to an external laboratory and with the rapid evolution to death, there was no time for that. It is worth emphasizing that due to the side effects that may occur with the rational use of antibiotics such as doxycycline, the its use without medical prescription, as occurred with the animal of the current report, may result in even worse consequences. Therefore, this use should always be discussed with the guardians, since it can generate irreversible consequences for the animals.

In order to control the gastrointestinal disorders resulting from the antibiotic therapy with doxycycline, maropitant citrate $\left(\mathrm{Cerenia}^{\circledR}\right)$ was used in the dosage reported in the study of SCHAFFER et al. (2020), at $1 \mathrm{mg} / \mathrm{kg}$, SC, SID. The choice of this drug was due to its central and peripheral antiemetic action, unlike other drugs with local action in the gastrointestinal tract (CLAUDE et al., 2014). The adoption of dexamethasone in the therapeutic protocol aimed to attenuate the immune-mediated manifestations of the disease (MYLONAKIS; THEODOROU, 2017). MOTA et al. (2019) also mentioned the use of dexamethasone as an enhancer of the bacteriostatic effect of doxycycline. In this case, the dose used was $0.3 \mathrm{mg} / \mathrm{kg}$, corroborating with the anti-inflammatory dose indicated in the literature for dogs infected with Anaplasma platys and $E$. canis (GAUNT et al., 2010). 
In addition to the aforementioned therapy, dipyrone $25 \mathrm{mg} / \mathrm{kg}$, IV, TID was administered to control the fever and diet supplementation was provided with $\mathrm{B}$ vitamins, nicotinamide, fructose, amino acids, macro and microminerals $\left(\right.$ Bionew $\left.^{\circledR}\right)$. The supplementation aimed to provide nutritional support, minimizing the worsening of the clinical picture. Dosages followed the recommendations of the manufacturer. Although therapy was initiated, the chronic clinical picture did not interrupt the progression of the disease, resulting in cardiorespiratory arrest. Even so, seven cycles of CPR were instituted, but without success. CPR was performed according to the algorithm presented in FLETCHER et al. (2012) based on the five domains: preparation and prevention, basic life support, monitoring, and post-cardiac arrest care.

The histopathology showed spleen with multifocal lymphoid follicles slightly hypoplastic, associated with the presence of rare erythrocytic cells in red pulp. In addition, the bone marrow consisted basically of unilocular adipose tissue, with small and rare islands of medullary cells. HARVEY (2001) pointed out that when the bone marrow of an adult dog is composed of more than $75 \%$ fat, associated with a reduction of the three cell types (erythroid, myeloid, and megakaryocytic), it is aplastic, coinciding with what was found in the present report.

According to COSTA et al. (2019), medullary aplasia has been described as pancytopenia secondary to hypoplasia of the erythroid, myeloid, and megakaryoid lineages, being characterized by the invasion of hematopoietic tissue by adipose tissue. The development may be caused by infections, like in the processes caused by Erhlichia canis. Aplastic animals are affected by intense neutropenia, which results in a compromised immune system and hematologic changes, including thrombocytopenia and anemia, as observed in this report.
Complementarily, LO et al. (2019) mentioned that in humans, severe pancytopenia in the medullary aplasia can be rapidly fatal if left untreated. Furthermore, some patients may be initially asymptomatic and cytopenia can be diagnosed on a routine examination. Bleeding and bruising can occur due to the thrombocytopenia, while the reduction in RBCs can cause dyspnea and pallor, and the sustained leukopenia predisposes to secondary infections. The absence of clinical manifestations for a certain period early in the infection led the bone marrow to become hyporesponsive before the diagnosis was established. This, together with the bacterial infection present, culminated in the development of medullary aplasia and greater parasitism by E. canis. As a result, we had an exacerbation of the clinical manifestations and consequent worsening of the clinical picture, leading the animal to death.

\section{CONCLUSION}

CME is a commonly encountered and diagnosed disease. Despite its subclinical presentation and rapid resolution in some cases, it is known that in severe chronic cases, the consequences are serious, as in this report, with presentation of important clinicopathological alterations, including medullary aplasia, related to the etiologic agent, or that resulted in death of the animal. Therefore, it is extremely important to perform and interpret complementary exams, as well as the systematic follow-up of animals presenting pancytopenia and lesions secondary to it. The detection of the severity of the disease allows the introduction of early and adequate treatment, with greater chances of survival, which did not occur in the present report.

\section{REFERENCES}

ALMOSNY, N. R. P. Hemoparasitoses em pequenos animais domésticos e como zoonoses. 1. ed. Rio de Janeiro: L. F. Livros, 2002. 135p.

CLAUDE, A. K. et al. Effects of Maropitant Citrato or Acepromazine on the Incidence of Adverse Events Associated with Hydromorphone Premedication in Dogs. Journal of Veterinary Internal Medicine, v. 28, p. 1414-1417, 2014.

COCKWILL, K. R. et. al. Granulocytic anaplasmosis in three dogs from Saskatoon, Saskatchewan. Canadian Veterinary Journal, v. 50, p. 835-840, 2009.

CONCEIÇÃO, L. G.; SANTOS, R. L. Sistema Tegumentar. In: SANTOS, R. L.;ALESSI, A. C. Patologia Veterinária. l. ed. São Paulo: Roca, 2011.

COSTA, J. N. R.; GOMES, A. A. D.; SANTOS, C. R. O.; MOROZ, L. R. Aplasia de medula óssea em cães - revisão de literatura. Revista Científica de Medicina Veterinária - Pequenos Animais eAnimais de Estimação, v. 3, p. 66-73, 2019.
FELDMAN,B.F;ZINKL,J.G.;JAIN, N.C. Schalm'sVeterinary hematology. 5. ed. Philadelphia: Lippincott Willians \& Wilkins, 2000. 1344p.

FIGHERA, R. A.; GRAÇA, D. L. Sistema Hematopoiético. In: SANTOS, R. L.;ALESSI, A. C. Patologia Veterinária. l. ed. São Paulo: Roca, 2011.

FLETCHER, D. J. et al. RECOVER evidence and knowledge gap analysis on veterinary CPR. Part 7: Clinical guidelines. Journal of Veterinary Emergency and Critical Care, v. 22, n. 1, p. 102-131, 2012.

FOURIE, J. J. et al. The efficacy of a generic doxycycline tablet in the treatment of canine monocytic ehrlichiosis. Journal of the South African Veterinary Association, v. 86, n. 1, p. 1-10, 2015.

GANT, P.; McBRIDE, D.; HUMM, K. Abnormal platelet activity in dogs and cats - impact and measurement. British Small Animal Veterinary Association, v. 61, p. 3-18, 2020.

GAUNT, S. D. et al. Experimental infection and co-infection of dogs with Anaplasma platys and Ehrlichia canis: hematologic, serologic and molecular findings. Parasites \& Vectors, v. 3, n. 33, p. 1-10, 2010. 
GOOCS, R. Therapeutic strategies for treatment of immune-mediated hemolytic anemia. Veterinary Clinics of North America: Small Animal Practice, v. 50, p. 1327-1349.

HARVEY, J. W. Atlas of veterinary hematology: blood and bone marrow of domestic animals. Philadelphia: Saunders, 2001.

IDEXX. SNAP 4Dx Plus Test - Test accuracy. IDEXX Laboratories (2016). Disponível em:<https:/www.idexx.com.br/files/snap-4dxplus-test-accuracy.pdf>. Acesso em: 20 dez. 2020.

LAPPIN, M. R. Doenças Riquetsiais Polissistêmicas. In: NELSON, R. W.; COUTO, C. G. Medicina interna de pequenos animais. 5. ed. Rio de Janeiro: Elsevier, 2015.

LO, C.; GLADER, B.; SAKAMOTO, K. M. Bone marrow failure. In: KEOHANE, E. M.; OTTO, C. N.;WALENCA, J. M. Rodak's hematology: clinical principles and applications. 6. ed. Saunders, 2019.

MOTA, N. M.; RAMALDES, F. M.; LEAL, D. R. Estudo retrospectivo de casos de erliquiose canina atendidos no centro universitário ICESP de Brasília. Ciência e Saúde Animal, v. 1, n. 1, p. 1-14, 2019.

MYLONAKIS, M. E.;THEODOROU, K. N. Canine monocytic ehrlichiosis: An update on diagnosis and treatment. Acta Veterinaria-Beograd, v. 67, п. 3, p. 299-317, 2017.

NAKACHI, A. C. H et. al. Canine ehrlichiosis: clinical, hematological, serological and molecular aspects. Ciência Rural, v. 38, n. 3, p. 766-770, 2008

PROCAJLO, A. et al. Monocytic Ehrlichiosis in dogs. Polish Journal of Veterinary Sciences, v. 14, n. 3, p. 515-520, 2011.

REILLY, J. T.; DOLAN, G. Proposed classification for the myelodysplasia/myelofibrosis syndromes. British Journal of Haematology, v. 79, n. 4, p. 653-659, 1991.
RODRÍGUEZ-ALARCÓN, C. A. et al. Demonstrating the presence of Ehrlichia canis DNA from different tissues of dogs with suspected subclinical ehrlichiosis. Parasites \& Vectors, v. 13, n. 158, p. 1-7, 2020.

SANTIAGO, M. B. et al. Pharmacokinetics and adverse effects of doxycycline in the treatment of Ehrlichiosis: theoretical foundations for clinical trials incanines. Revista MVZCórdoba,v.22, p.6052-6071,2017.

SAVADELIS, M. D. et. al. Efficacy and side effects of doxycycline versus minocycline in the three-dose melarsomine canine adulticidal heartworm treatment protocol. Parasites \& Vectors, v. 11, n. 671, p. 1-7, 2018.

SCHAFFER, P.A. et al. Delayed diagnosis of fatal pneumonic canine plague: clinical and pathologic features in two naturally infected Colorado dogs. BMCVeterinary Research, v. 16, п. 160, p. 1-8, 2020.

SCHULZ, B. S. et al. Suspected side effects of doxycycline use in dogs-a retrospective study of 386 cases. Veterinary Record, v. 169, ก. 9, 2011

SOUSA, V. R. F.; ALMEIDA, A. B. P. F.; BARROS, L. A.; SALES, K. G.; JUSTINO, C. H. S.; DALCIN, L.; BOMFIM, T. C. B. Avaliação clínica e molecular de cães com erliquiose. Ciência Rural, v. 40, n. 6, p. 1309-1313, 2010.

SOUZA, D. M. B et al. Erliquiose transmitida aos cães pelo carrapato marrom (Rhipicephalus sanguineus). Ciência Veterinária nos Trópicos, v. 15, n. 1, p. 2l-31, 2012.

TERRA, V. J. B. Transfusão sanguínea em cães e gatos - revisão. PUBVET - Publicações em Medicina Veterinária e Zootecnia, v. 4, ก. 23, 2010.

UENO, T. E. H. et al. Ehrlichia canis em cães atendidos em hospital veterinário de Botucatu, Estado de São Paulo, Brasil. Revista Brasileira de Parasitologia Veterinária, v. 18, n. 3, p. 57-61, 2009. 